\title{
Chassis Maintenance and Vehicle Power Transfer Learning: The Effectiveness of STEM on Students' Critical Thinking Ability
}

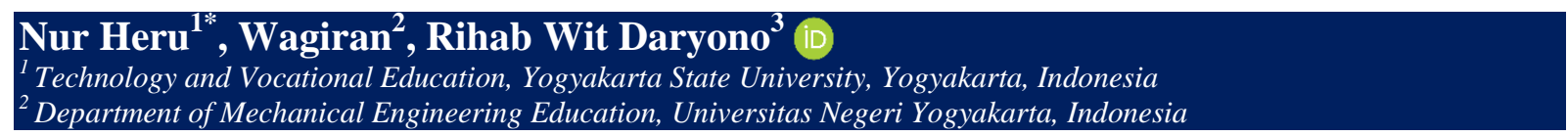

\section{A R T I C L E I N F O}

Article history:

Received September 10, 202

Revised September 11, 2021

Accepted October 12, 2021

Available online November 25, 2021

\section{Kata Kunci.}

STEM, Kemampuan Berpikir Kritis,

Pemeliharaan Sasis

Keywords:

STEM, Critical Thinking Ability, Chassis Maintenance

DOI:

https://dx.doi.org/10.23887/jet.v5i4.4 0534

\begin{abstract}
A B S T R A K
Rendahnya kemampuan berpikir kritis siswa pada pembelajaran pemeliharaan sasis dan pemindah tenaga sehingga tidak tercapainya kompetensi yang dibutuhkan. Penelitian ini bertujuan untuk menganalisis kemampuan berpikir kritis pada pembelajaran pemeliharaan sasis dan pemindah tenaga yang di ajarkan menggunakan model pembelajaran Science, Technology, Engineering, and Mathemathic (STEM) dan model pembelajaran konvensional. Penelitian ini termasuk jenis penelitian semu (quasi experiment). Populasi dalam penelitian ini siswa kelas XI TKR 1 dan XI TKR 2 sebanyak 69 siswa. Teknik pengumpulan data menggunakan teknik dokumentasi dan teknik tes. Teknik analisis data menggunakan analisis deskripif dan analisis inferensial yang meliputi uji normalitas, uji homogenitas, dan uji hipotesis. Analisis deskriptif diperoleh mean 83.49 dengan kategori sangat tinggi dan sangat efektif. Data tersebut di buktikan dengan Uji $t$ diperoleh nilai $t_{\text {hitung }}$ yaitu 8.045 dan ttabel yaitu df $67=$ 2.00 maka dapat di putuskan bahwasanya $\mathrm{H}_{0}$ ditolak dan $\mathrm{H}_{a}$ diterima karena $t_{\text {hitung }}>t_{\text {tabel }}$ sehingga dapat disimpulkan bahwasanya model pembelajaran Science, Technology, Engeneering, and Mathematic (STEM) efektif digunakan untuk meningkatkan kemampuan berpikir kritis dibanding menggunakan model pembelajaran konvensional.
\end{abstract}

\section{A B S T R A C T}

The low critical thinking ability of students in the chassis maintenance and power transfer learning so that the required competencies are not achieved. This study aims to analyze critical thinking skills in chassis maintenance and power transfer learning which is taught using the Science, Technology, Engineering, and Mathematical (STEM) learning model and the conventional learning model. This research is a quasi-experimental type of research. The population in this study were students of class XI TKR 1 and XI TKR 2 as many as 69 students. Data collection techniques used documentation technique and test technique. The data analysis technique used descriptive analysis to know the category of students' critical thinking skills and inferential analysis, including normality, homogeneity, and hypothesis by using a t-test to know the comparison of students' critical thinking skills in learning chassis maintenance and power transfer which is taught using the Science, Technology, Engineering, And Mathematical (STEM) learning model and conventional learning models. This study shows that descriptive analysis obtained a Mean of 83.49 that was classified into a very high category and very effective category. The $t$-test proves the data. The $t_{\text {value }}$ value is 8045 , and the $t_{\text {table }}$ is df $67=2,000$, so it can be decided that $\mathrm{H}_{0}$ is rejected. $\mathrm{H}_{\mathrm{a}}$ is accepted because $t_{\text {value }}>t_{\text {table }}$, so it can be concluded that the Science, Technology, Engineering, and Mathematical (STEM) learning model is effectively used to improve critical thinking skills compared to using conventional learning models.

This is an open access article under the $\underline{C C B Y-S A}$ license.

Copyright (C) 2021 by Author. Published by Universitas Pendidikan Ganesha.

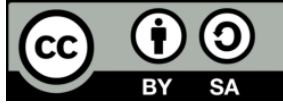

\section{INTRODUCTION}

Education has now entered the 21 st century and is in the era of the industrial revolution 4.0, where digital technology in the learning process is the main component (Cetrulo \& Nuvolari, 2019; Kolesnichenko et al., 2019). These changes require the readiness of adequate human resources (HR) to be ready and able to compete on a global scale. Improving the quality of human resources to follow the development of revolution 4.0 can be done through education, ranging from primary education to higher education (Febrianti et al., 2018; Khan et al., 2020). Each student is expected to master skills that can encourage students to be able to solve complex and socio-emotional problems (Elizabeth L. \& Adams, 2021; Patacsil \& S. Tablatin, 2017). To achieve this goal, professional educators are needed who can form creative, innovative, and competitive generations by optimizing the use of technology as a tool in the learning process (Alonzo, 2018; Cifrian et al., 2020). Vocational education 
is secondary education that aims to prepare students to work in specific fields professionally with hard skills and soft skills competencies (Daryono et al., 2021; Saifurrahman et al., 2021). In addition, vocational education is also a means of acculturating students' self to seek and find talents, skills, and abilities as preparation for the world of work to have expertise and existence (Kusuma et al., 2021; Setyadi et al., 2021; Supriyadi et al., 2020). To achieve this goal, input, process, and output in education must also be appropriate because education affects graduates' quality (Liu et al., 2020; Suwanroj et al., 2019). The expected graduates' abilities have skills, mastering technology, having a broad and professional knowledge. However, in reality, Indonesia still has inadequate graduate results due to the low quality of education (Daryono et al., 2021).

Education plays a role in printing students to be able to think critically according to their scientific field. To achieve this ability, the learning process applied in the classroom must support the development of students' critical thinking skills (Juano \& Pardjono, 2016; Seibert, 2021). Students need critical thinking skills to deal with conditions in society or everyday life (Juano \& Pardjono, 2016). In educational institutions critical thinking is to equip students with skills and dispositions according to the needs that exist in the industry (Fung \& Liang, 2019). Improving critical thinking skills is the goal of education, because through these skills students better understand what they are learning to be developed further (Liang \& Fung, 2020; Rahayu \& Kuswanto, 2021). Open and critical thinking patterns will greatly assist children in gaining more meaningful knowledge. Critical thinking skills involve several assumptions that must be solved and develop a design problem (Adair \& Jaeger, 2016; Ahern et al., 2019). During the learning process, students will be able to develop ideas about problems in learning. Measuring students' abilities is very important in improving skills and providing useful feedback for teachers and students (Braun et al., 2020; Seibert, 2021). In the short term, students will be trained to find ideas in every problem they face in learning. Meanwhile, Students will have the ability to accumulate all possible problem solving more accurately. Efforts to strengthen critical thinking skills must start from elementary school age (Çelik et al., 2018; Liang \& Fung, 2020).

Critical thinking skills are useful in a series of process activities to solve problems, make decisions, analyze assumptions, and conduct scientific research. Critical thinking ability is a convergent thinking pattern. Convergent thinking is the process of processing information from various perspectives to obtain a conclusion. According to (Dakabesi \& Luoise, 2019; Nurnia \& Tasina, 2020). Critical thinking is someone whose thinking is always critical and it is easier to solve problems and can create new innovations. Critical thinking relates to the use of cognitive skills or strategies that increase the likelihood of obtaining the desired impact (Miharja et al., 2019). Critical thinking stimulation activities during a pandemic are still universal, such as critical thinking stimulation through conversations between children and parents about the reasons why learning from home (Lavi et al., 2021; Miharja et al., 2019). Critical thinking skills in the 21st century can be developed through appropriate management or learning processes in real situations (Seibert, 2021; Shavelson et al., 2019). Critical thinking as a capacity that combines cognitive skills and affective disposition (Kleemola et al., 2021; Miharja et al., 2019). It involves an action aimed at producing interpretation, analysis, evaluation, inference. Critical thinking is a skill to evaluate credibility, identify assumptions, conclusions, ask questions with appropriate clarification and provide sources from various interesting references with various explanations that are appropriate to the existing context (Dakabesi \& Luoise, 2019; Shavelson et al., 2019).

The problem of critical thinking skills is caused by the weakness of the learning model which is still monotonous and student-centered so that the ability is still lacking in answering questions with reasons, asking questions when they do not understand the material presented, when analyzing questions, concluding problems, and evaluating problems (Kleemola et al., 2021; Nurnia \& Tasina, 2020; Seibert, 2021). Education should equip students to solve problems and be given the opportunity for students to be able to solve and analyze problems and be able to express their opinions so that the goals of critical thinking skills are achieved. This can train students in developing their creative abilities in everyday life. But in reality, learning in Vocational High Schools (VHS) still tends to be conventional, not maximizing the scientific approach. Therefore, to improve the quality of students as human resources, it is necessary to apply the STEM learning model to improve critical thinking skills (Han et al., 2015; Lavi et al., 2021). STEM is an approach that refers to the components of knowledge, technology, engineering, and mathematics (Gok, 2021; Han et al., 2015; Mikhaylovsky et al., 2021). In STEM learning, students learn skills and knowledge simultaneously, so there is a connecting line that makes science, technology, engineering, and mathematics known and applied together in the learning process. The application of STEM can help develop knowledge, help answer questions based on investigations to become inventors, and help students create new knowledge creations or innovators (Afriana et al., 2016; Mikhaylovsky et al., 2021). Therefore, changing the curriculum to implement STEM learning in schools is needed to be able to prepare students to face economic changes (Lavi et al., 2021; Sleeman et al., 2019; Vossen et al., 2020).

STEM-based learning can increase motivation, provide experience in manufacturing techniques, and improve achievement in exams. The application of the STEM model is problem-solving-based learning that places the process of scientific investigation and the application of mathematics in designing technology as a form of problem-solving (Gok, 2021; Sleeman et al., 2019; Vossen et al., 2020). In the problem-solving process, 
students' critical thinking skills are needed. Critical thinking is a reflective process that focuses on making real decisions and requires students to be able to make and justify what to believe and what to do next (Kleemola et al., 2021; Shavelson et al., 2019). Based on the discussion above, the STEM learning model can improve students' critical thinking skills. Chassis Maintenance and Power Transfer lessons aimed at achieving maximum competence and adding skills that are currently needed by the industry. Therefore, it is necessary to conduct research to prove that the STEM learning model can improve students' critical thinking skills in learning chassis maintenance and power transfer. This research was conducted at SMK Ma'arif Al-Munawwir Yogyakarta based on Islamic Boarding School

\section{METHOD}

This research uses a quasi-experimental type of research. The research design used in this study is the pretest and posttest group design. The development of one group pretest and posttest design, namely by taking one measurement in front (pre-test) before treatment (treatment) and after measuring again (post-test). In this study, two groups were used to describe the initial conditions of students, namely the experimental class group and the control class group. Each group uses a pretest and posttest to determine critical thinking skills. The following is the pretest and posttest group design research design as follows:

Table 1. Research Design

\begin{tabular}{llcc}
\hline \multicolumn{1}{c}{ Class } & \multicolumn{1}{c}{ Postest } & Treatment & Posttest \\
\hline Experiment & Critical thinking skills & STEM & Critical thinking skills \\
Control & Critical thinking skills & Conventional & Critical thinking skills \\
\hline
\end{tabular}

The population is a generalization area consisting of objects/subjects with certain qualities and characteristics determined by the researcher to study and then draw conclusions (Heru, 2020; Siregar, 2020). The population in this study were students of class XI TKR 1 and XI TKR 2, as many as 69 students at SMK Ma'arif Al-Munawwir Yogyakarta. This research was conducted for 6 months at SMK Ma'arif Yogyakarta. In this study, two groups were used: the first group of students was given special treatment as an experimental class using the STEM learning model. In contrast, the second group was given as a control class using the conventional learning model. The following is a grid of students' critical thinking skills:

Tabel 2. Grid of instrument

\begin{tabular}{llc}
\hline Critical thinking & Indicator & Item \\
\hline Ability to identify problems & $\begin{array}{l}\text { Explaining the differential and observing the picture } \\
\text { Observing the propeller shaft, clutch and } \\
\text { transmission along with pictures }\end{array}$ & $\begin{array}{l}1,2 \\
\text { Able to formulate a problem }\end{array}$ \\
$\begin{array}{l}\text { Formulate and types of differential, propeller, clutch } \\
\text { and transmission damage }\end{array}$ & 5,6 \\
$\begin{array}{l}\text { Able to determine the consequences of a } \\
\text { problem }\end{array}$ & $\begin{array}{l}\text { Knowing the effects on the propeller, clutch and } \\
\text { transmission }\end{array}$ & 7,8 \\
Able to express and solve problems & $\begin{array}{l}\text { Can solve problems or damage that exists in the } \\
\text { propeller, clutch and transmission }\end{array}$ & 9,10 \\
\hline
\end{tabular}

This research instrument is in the form of a critical thinking ability test in the learning of Chassis Maintenance and Vehicle Power Transfer, especially in the competency system for Diagnosing Manual Transmission Damage. There are 10 question items in this test, giving questions at the beginning and end of learning. The validity test is carried out with the help of expert lecturers so that the questions given to students deserve to be tested. This study uses data analysis techniques in this study is descriptive analysis that compares the value of critical thinking skills and inferential analysis, including normality test, homogeneity test, and hypothesis testing.

\section{RESULT AND DISCUSSION}

\section{Result}

Discussion The following will present the data that has been generated from the research, namely descriptive analysis, and inferential analysis. The tendency of critical thinking skills in learning Chassis Maintenance and Vehicle Power Transfer, especially in the competency system for Diagnosing Manual 
Transmission Damage SMK Ma'arif Yogyakarta using the STEM (Science, Technology, Engineering, and Mathematical) learning model and the Conventional learning model, is proven by the results of the descriptive analysis. The experimental class with a minimum score of 52, a maximum score of 96, an ideal mean of 83.49, and Std. Deviation 11,716 and the control class with a minimum score of 30, a total score of 90, the perfect mean of 56.32, and Std. Deviation 16,055. So it can be concluded that the Science, Technology, Engineering, and Mathematical (STEM) learning model on students' critical thinking skills is effective for chassis maintenance learning is very effective by showing the results of 83.49 with a very high category. The following histogram graph also proves this for the experimental class and the control class:

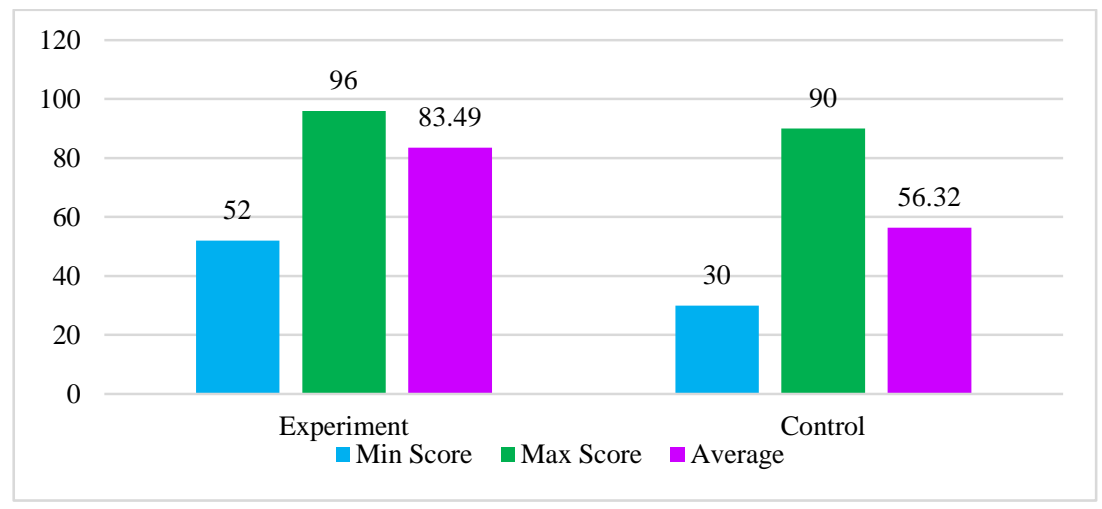

Figure 1. Pretest and Postest Scores

Based on figure 1, it is found that the post-test mean score of the experimental group is 83.49 and the control group is 56.32. This states that the data on the value of the critical thinking skills of mathematics in the experimental group which were taught through the STEM (Science, Technology, Engineering, and Mathematical) learning model assisted by concrete media have a higher average than the control group taught using conventional learning. Based on the results of the inferential analysis that there is a very significant difference in critical thinking skills in the learning of Chassis Maintenance and Vehicle Power Transfer, especially in the competency system for Diagnosing Manual Transmission Damage at SMK Ma'arif AlMunawwir Yogyakarta using the STEM (Science, Technology, Engineering, and Mathematical) learning model and Conventional learning model. In the data, the average score of critical thinking skills in the learning of Chassis Maintenance and Vehicle Power Transfer, especially in the competency system for Diagnosing Manual Transmission Damage is obtained, which is taught with the STEM learning model with a very high category compared to conventional learning models, so from the data obtained, it can be concluded that there is an effect of the STEM learning model on critical thinking skills in the learning of Chassis Maintenance and Vehicle Power Transfer.

The experimental class is normally distributed with a value of $(\alpha)=0.05(0.065>0.05)$ while the control class has a value of $(\alpha)=0.05(0.959>0.05)$. With these data, it can be concluded that the experimental class uses the STEM model while the control class uses the conventional learning model with a normal distribution. The homogeneity can be obtained sig value: 0.107 where $P>0.05$. With these data, it can be concluded that sig: $0.107>0.05$, the variance is the same or homogeneous. Testing this hypothesis is effective if the Science, Technology, Engineering, and Mathematical (STEM) learning model increases critical thinking skills compared to conventional learning models. The value of $t_{\text {value }}>t_{\text {table }}$ then $\left(H_{a}\right)$ is accepted. For the results of the analysis, the value of $t_{v a l u e}$ is 8045 and $t_{\text {table }}$ is $\mathrm{df} 67=2,000$; it can be decided that $\left(\mathrm{H}_{0}\right)$ is rejected and $\left(\mathrm{H}_{\mathrm{a}}\right)$ is accepted because $t_{\text {value }}>t_{\text {table }}$ which is a practical Science, Technology, Engineering, and Mathematics (STEM) learning model used to improve critical thinking skills compared to using conventional learning models.

\section{Discussion}

Critical thinking skills in chassis learning and power transfer using the STEM learning model are included in the very high category, so the effectiveness of the STEM learning model can encourage students to be more active in the learning process. It can be stated that the ability to think critically is a convergent thinking pattern. Convergent thinking is the process of processing information from various perspectives to obtain a conclusion. Critical thinking is a skilled and responsible process when someone studies a problem from all points of view and is involved in investigations so that they can get the best opinion, judgment or consideration using their intelligence to conclude (Susanti \& Krisdiana, 2021; Dakabesi \& Luoise, 2019). Critical thinking is concerned with using cognitive skills or strategies that increase the likelihood of obtaining the desired impact . 
There are five domains of expertise with various indicators regarding critical thinking, : (1) interpretation, understanding and expressing the meaning or importance of different experiences, situations, data, events, assessments, findings, beliefs, rules, procedures or criteria; (2) analysis identifies trends and actual conclusions on the relationship between statements and questions, concepts, descriptions or other forms of representation intended to express beliefs, judgments, experiences, thoughts, information and opinions; (3) evaluation to assess the credibility of questions or other important representations or depictions of people's perceptions; (4) conclusions to analyze and believe the elements needed to draw reasonable conclusions, to form hypotheses and estimates, to take into account relevant information and to take into account the consequences that flow from data, statements, principles, evidence, judgments, beliefs, opinions, concepts, a description of the data, statement, or other form of representation; (5) explanation, to state the results of thoughts, to state the results of thinking, to impress thoughts in terms of evidence, concepts, methods, criteria and contextual considerations that form the basis of one's thinking and to present people's thoughts in the form of a strong statement (Braun et al., 2020; Oser \& Biedermann, 2019).

The current problem in education is a failure in the learning process, which still uses conventional learning models. Traditional learning to improve critical thinking skills is very low. This has been proven by the research above. The results obtained Mean 56.32 with a deficient category. It is not surprising that the effectiveness of the conventional model still cannot overcome the existing problems because this model is still teacher-centered, so students cannot take an active role in the process. This is where the role of learning that can be related to high-quality learning outcomes, which can make students active and critical (Balwant \& Doon, 2021; Braun et al., 2020; Seibert, 2021), for learning models that can foster necessary thinking skills are Science, Technology, Engineering, and Mathematics learning models STEM. The STEM learning model has been effective in increasing students' critical thinking skills and has been proven in this study with a Mean result of 83.49 with a very high category. From these results, the STEM learning model can develop well and effectively to improve student's critical thinking skills. Students' critical thinking skills claim a positive effect on solving problems. This makes students strive to solve a problem and develop critical thinking skills (Amin et al., 2020; Vossen et al., 2020). The results of this study were strengthened by stating that there was an increase in using the STEM learning model on 21st century skills development ( Han et al., 2015; Lavi et al., 2021; Sleeman et al., 2019). The results of the research that has been done show positive results for the STEM learning model to improve critical thinking skills.

The Science, Technology, Engineering, and Mathematical (STEM) learning model teaches students to answer the challenges that exist in the world of education. In STEM, students are required to learn how and how to solve a problem through group discussions conducted during learning. Students collect various information and answers that are sought in various relevant sources to solve problems. In learning, students are given problems to discuss in their groups so that they can be solved. STEM provides students with learning experiences that encourage critical thinking and problem solving that build on their natural connection to discipline and practice. STEM can make science learning more fun. And can increase motivation and encourage students to be critical (Conradty \& Bogner, 2020; Mikhaylovsky et al., 2021). Each student is trained to solve a problem in the hope of being active in the learning process (Isdianti et al., 2021; Khan et al., 2020), with an interesting learning model that allows them to develop their skills and knowledge to become independent students (Gok, 2021; Hallström \& Schönborn, 2019; Khan et al., 2020). Students and teachers have a close relationship that aims to foster students to be critical and active. STEM teaches students to combine career, technology, and skills needed while practicing in school workshops. Teachers must always be active to build a pleasant learning atmosphere so that students do not become bored.

\section{CONCLUSION}

The STEM-based learning model is effective in improving students' critical thinking skills at SMK Ma'arif Al-Munawwir Yogyakarta compared to conventional learning models. This result is also reflected in the average score of the critical thinking ability test in the experimental group which is higher than the average score of the control group. For students who are enthusiastic about learning, it also shows very well for learning using the STEM model.

\section{REFERENCES}

Adair, D., \& Jaeger, M. (2016). Incorporating Critical Thinking into an Engineering Undergraduate Learning Environment. International Journal of Higher Education, 5(2). https://doi.org/10.5430/ijhe.v5n2p23.

Afriana, J., Permanasari, A., \& Fitriani, A. (2016). Penerapan Project Based Learning Terintegrasi STEM untuk Meningkatkan Literasi Sains Siswa Ditinjau dari Gender. Jurnal Inovasi Pendidikan IPA, 2(2), 202. https://doi.org/10.21831/jipi.v2i2.8561. 
Ahern, A., Dominguez, C., McNally, C., O’Sullivan, J. J., \& Pedrosa, D. (2019). A literature review of critical thinking in engineering education. Studies in Higher Education, 44(5), 816-828. https://doi.org/10.1080/03075079.2019.1586325.

Alonzo, A. C. (2018). An Argument for Formative Assessment with Science Learning Progressions. Applied Measurement in Education, 31(2), 104-112. https://doi.org/10.1080/08957347.2017.1408630.

Amin, S., Utaya, S., Bachri, S., Sumarmi, \& Susilo, S. (2020). Effect of Problem-Based Learning on Critical Thinking Skills and Environmental Attitude. Journal of Physics: Conference Series, 1810, (1), 1-5. https://doi.org/10.1088/1742-6596/1810/1/012060.

Balwant, P. T., \& Doon, R. (2021). Alternatives to the Conventional 'Oxford' Tutorial Model: A Scoping Review. International Journal of Educational Technology in Higher Education (Vol. 18, Issue 1). https://doi.org/10.1186/s41239-021-00265-y..

Braun, H. I., Shavelson, R. J., Zlatkin-Troitschanskaia, O., \& Borowiec, K. (2020). Performance Assessment of Critical Thinking: Conceptualization, Design, and Implementation. Frontiers in Education, 5. https://doi.org/10.3389/feduc.2020.0015.

Çelik, Ö., Çokçalışkan, H., \& Yorulmaz, A. (2018). Investigation of the Effect of Pre-Service Classroom Teachers' Critical Thinking Disposition on Their Media Literacy. International Journal of Evaluation and Research in Education (IJERE), 7(3), 194-202. http://doi.org/10.11591/ijere.v7i3.13960.

Cetrulo, A., \& Nuvolari, A. (2019). Industry 4.0: Revolution or Hype? Reassessing Recent Technological Trends and Their Impact on Labour. Journal of Industrial and Business Economics, 46(3), 391-402. https://doi.org/10.1007/s40812-019-00132-y.

Cifrian, E., Andrés, A., Galán, B., \& Viguri, J. R. (2020). Integration of Different Assessment Approaches: Application to a Project-Based Learning Engineering Course. Education for Chemical Engineers, 31, 62-75. https://doi.org/10.1016/j.ece.2020.04.006.

Conradty, C., \& Bogner, F. X. (2020). STEAM Teaching Professional Development Works: Effects on Students' Creativity and Motivation. Smart Learning Environments (Vol. 7, Issue 1). https://doi.org/10.1186/s40561-020-00132-9.

Dakabesi, D.-, \& Luoise, I. S. Y. (2019). The Effect of Problem Based Learning Model on Critical Thinking Skills in the Context of Chemical Reaction Rate. Journal of Education and Learning (EduLearn), 13(3), 395-401. https://doi.org/10.11591/edulearn.v13i3.13887.

Daryono, R. W., Rochmadi, S., \& Hidayat, N. (2021). Development and Validation of Video-Based Learning Media to Increase Competency Achievement in Civil Engineering Education. Journal of Physics: Conference Series, 1833(1), 012022. https://doi.org/10.1088/1742-6596/1833/1/012022.

Elizabeth L., \& Adams. (2021). The Effect of a Middle Grades STEM Initiative on Students' Cognitive and Non-Cognitive Outcomes. Studies in Educational Evaluation, 68(April 2020). https://doi.org/10.1016/j.stueduc.2021.100983.

Febrianti, R. A. M., Haizam Mohd Saudi, M., Kaniawati, K., \& Hermina, N. (2018). Transformation of Digital Marketing in the 4.0 Industry Revolution: A Study on Batik MSMEs. International Journal of Engineering \& Technology, 7(4.34), 352-357. https://doi.org/10.14419/ijet.v7i4.34.25779.

Fung, D. C.-L., \& Liang, T. W. (2019). Fostering critical thinking through collaborative group work: Insights from Hong Kong. Springer Singapore. https://doi.org/10.1007/978-981-13-2411-6.

Gok, T. (2021). The Development of the STEM (Science, Technology, Engineering, and Mathematics) Attitude and Motivation Survey Towards Secondary School Students. International Journal of Cognitive Research in Science Engineering and Education, 9(1), 105-119. https://doi.org/10.23947/2334-84962021-9-1-105-119.

Hallström, J., \& Schönborn, K. J. (2019). Models and Modelling for Authentic STEM Education: Reinforcing the Argument. International Journal of STEM Education (Vol. 6, Issue 1). https://doi.org/10.1186/s40594-019-0178-Z.

Han, S., Yalvac, B., Capraro, M. M., \& Capraro, R. M. (2015). In-service Teachers' Implementation andUnderstanding of STEMProject Based Learning. EURASIA Journal of Mathematics, Science and Technology Education, 11(1), 63-76. https://doi.org/10.12973/eurasia.2015.1306a.

Isdianti, M., Nasrudin, H., \& Erman, E. (2021). The effectiveness of STEM Based Inquiry Learning Packages to Improving Students' Critical Thinking Skill. Journal for the Education of Gifted Young Scientists, 9(3), 223-232. https://doi.org/10.17478/jegys.832239.

Juano, A., \& Pardjono, P. (2016). Pengaruh Pembelajaran Problem Posing terhadap Kemampuan Berpikir Kritis dan Komunikasi Matematis Siswa Kelas V SD. Jurnal Prima Edukasia, 4(1), 46. https://doi.org/10.21831/jpe.v4i1.7801.

Khan, Z., Soundararajan, V., \& Shoham, A. (2020). Global Post-Merger Agility, Transactive Memory Systems and Human Resource Management Practices. Human Resource Management Review, 30(1), 1-10. https://doi.org/10.1016/j.hrmr.2019.100697. 
Kleemola, K., Hyytinen, H., \& Toom, A. (2021). Exploring Internal Structure of a Performance-Based Critical Thinking Assessment for New Students in Higher Education. Assessment and Evaluation in Higher Education. https://doi.org/10.1080/02602938.2021.1946482.

Kolesnichenko, E. A., Radyukova, Y. Y., \& Pakhomov, N. N. (2019). The Role and Importance of Knowledge Economy as a Platform for Formation of Industry 4.0. In E. G. Popkova, Y. V. Ragulina, \& A. V. Bogoviz (Eds.), Industry 4.0: Industrial Revolution of the 21st Century (Vol. 169, pp. 73-82). Springer International Publishing. https://doi.org/10.1007/978-3-319-94310-7_7.

Kusuma, W. M., Sudira, P., Hasibuan, M. A., \& Daryono, R. W. (2021). The Perceptions of Vocational School Students of Video Animation-Based Learning Media to Operate Lathes in Distance Learning. Journal of Education Technology, 5(2), 200. https://doi.org/10.23887/jet.v5i2.33139.

Lavi, R., Tal, M., \& Dori, Y. J. (2021). Perceptions of STEM Alumni and Students on Developing 21st Century skills Through Methods of Teaching and Learning. Studies in Educational Evaluation, 70. https://doi.org/10.1016/j.stueduc.2021.101002.

Liang, W., \& Fung, D. (2020). Development and Evaluation of a WebQuest-Based Teaching Programme: Students' Use of Exploratory Talk to Exercise Critical Thinking. International Journal of Educational Research, 104(August), 1-13. https://doi.org/10.1016/j.ijer.2020.101652.

Liu, X., Chen, Y., Yang, Y., Liu, B., Ma, C., Craig, G. R., \& Gao, F. (2020). Understanding Vocational Accounting Students' Attitudes Towards Sustainable Development. Journal of Vocational Education \& Training, 1-21. https://doi.org/10.1080/13636820.2020.1760333.

Mikhaylovsky, M. N., Karavanova, L. Zh., Medved, E. I., Deberdeeva, N. A., Buzinova, L. M., \& Zaychenko, A. A. (2021). The Model of STEM Education as an Innovative Technology in the System of Higher Professional Education of the Russian Federation. Eurasia Journal of Mathematics, Science and Technology Education, 17(9), em2007. https://doi.org/10.29333/ejmste/11173.

Nurnia, N., \& Tasina, H. A. (2020). Critical Thinking of Field Independent Students; which Model of Teaching is more Supportive? JTP - Jurnal Teknologi Pendidikan, 22(2), 108-116. https://doi.org/10.21009/jtp.v22i2.16018.

Patacsil, F., \& S. Tablatin, C. L. (2017). Exploring the Importance of Soft and Hard Skills as Perceived by IT Internship Students and Industry: A Gap Analysis. Journal of Technology and Science Education, 7(3), 347-368. https://doi.org/10.3926/jotse.271.

Rahayu, M. S. I., \& Kuswanto, H. (2021). The Effectiveness of the Use of the Android-Based Carom Games Comic Integrated to Discovery Learning in Improving Critical Thinking and Mathematical Representation Abilities. Journal of Technology and Science Education, 11(2), 270. https://doi.org/10.3926/jotse.1151.

Saifurrahman, M., Sudira, P., \& Daryono, R. W. (2021). The Determinant Factor of the Principal Leadership Solutions in Facing the 21st-Century Learning. Jurnal Pendidikan dan Pengajaran, 54(2), 230-243. http://dx.doi.org/10.23887/jpp.v54i2.34102.

Seibert, S. A. (2021). Problem-Based Learning: A Strategy to Foster Generation Z's Critical Thinking and Perseverance. Teaching and Learning in Nursing, 16(1), 85-88. https://doi.org/10.1016/j.teln.2020.09.002.

Setyadi, M. R. A., Triyono, M. B., \& Daryono, R. W. (2021). The Influence of Industrial Work Practices and Workshop Infrastructure Facilities on Work Readiness of Students. Journal of Physics: Conference Series, 1833(1), 1-8. https://doi.org/10.1088/1742-6596/1833/1/012029.

Shavelson, R. J., Zlatkin-Troitschanskaia, O., Beck, K., Schmidt, S., \& Marino, J. P. (2019). Assessment of University Students' Critical Thinking: Next Generation Performance Assessment. International Journal of Testing, 19(4), 337-362. https://doi.org/10.1080/15305058.2018.1543309.

Sleeman, J., Lang, C., \& Dakich, E. (2019). Social Media, Learning and Connections for International Students: The Disconnect Between what Students Use and the Tools Learning Management Systems Offer. Australasian Journal of Educational Technology, 36(4), 44-56. https://doi.org/10.14742/ajet.4384.

Stehle, S. M., \& Peters-Burton, E. E. (2019). Developing Student 21st Century Skills in Selected Exemplary Inclusive STEM High Schools. International Journal of STEM Education (Vol. 6, Issue 1). https://doi.org/10.1186/s40594-019-0192-1.

Supriyadi, E., Indro H., Y., Priyanto, E., \& Surwi, F. (2020). Students' Evaluation on Teaching in Vocational and Technical Schools. International Journal of Instruction, 13(2), 621-636. https://doi.org/10.29333/iji.2020.13242a.

Susanti, V. D., \& Krisdiana, I. (2021). The Effect of Literacy Skills on the Critical Thinking Skills of Mathematics Education Students. AL-ISHLAH: Jurnal Pendidikan, 13(1), $72-79$. https://doi.org/10.35445/alishlah.v13i1.371. 
Suwanroj, T., Leekitchwatana, P., \& Pimdee, P. (2019). Confirmatory Factor Analysis of the Essential Digital Competencies for Undergraduate Students in Thai Higher Education Institutions. Journal of Technology and Science Education, 9(3), 340. https://doi.org/10.3926/jotse.645.

Vossen, T. E., Tigelaar, E. H., Henze, I., De Vries, M. J., \& Van Driel, J. H. (2020). Student and Teacher Perceptions of the Functions of Research in the Context of a Design-Oriented STEM Module. International Journal of Technology and Design Education, 30(4), 657-686. https://doi.org/10.1007/s10798-019-09523-7. 